\title{
Psychological contract-based Consumer Repurchase behavior On Social commerce platform: An Empirical study
}

\author{
Hussain Shahbaz ${ }^{1}$, Ying $\mathrm{Li}^{{ }^{*}}$, and Wenli $\mathrm{Li}^{1}$ \\ ${ }^{1}$ School of Economics and Management, Dalian University of Technology \\ Dalian, Liaoning 116024 - China \\ [e-mail: raihussain@mail.dlut.edu.cn,yingli@dlut.edu.cn, wlli@dlut.edu.cn] \\ *Corresponding author: Ying Li
}

Received July 17, 2019; revised December 12, 2019; revised January 29, 2020; accepted March 4, 2020; published May 31, 2020

\begin{abstract}
Social commerce, integration of social media and e-commerce, provides potential opportunities for consumers to talk about their ideas and exchange product-related information on online shopping platforms. Given the substantial prospects related to business opportunities and consumers' perceptions, this study explores the factors driving fulfillment of the psychological contract in social commerce platforms. This research proposes, examines, and proves a theoretical model for the post-purchase behavior of the consumers, through an empirical investigation of online questionnaire-based data, gathered from 367 consumers in a cross-sectional setting. Results show that the fulfillment of psychological contract, consumer loyalty, and affective commitment fully mediate the impact of consumer trust on platform and repurchase intention. The level of commitment toward the consumer by the platform is strongly related to the degree of consumer trust, which is reciprocated through re-purchase intentions. This study offers essential theoretical implications with regards to the social exchange theory, attribution theory, and an moderating effect of the platform empathy on consumers' trust-psychological contract fulfillment relationship. Likewise, this research has significant implications for practitioners and managers.
\end{abstract}

Keywords: Psychological Contracts, Repurchase Behavior, Social Commerce, Consumer Trust in Platform 


\section{Introduction}

The development of web 2.0, along with the advancement of information technology, has made things easier for consumers and marketers to communicate massive amounts of information efficiently and effectively. Online shopping market (or platform) on social media has become one of the fastest-growing developments in social commerce, accompanied by the arising trust of the consumers and, overall, flourishing prospects in such markets. For ensuring the continuance of trust in online platforms, repurchase intention is a critical factor. "65\% of a platform's business originates from existing consumers, and it costs five times the amount of to pull in another consumer than to keep a current one satisfied" (Sourced: Gartner). Therefore, to hold existing consumers to make repeated purchases is considered to be a significant concern for social commerce platforms. Along these lines, it is crucial to draw on other hypothetical viewpoints to recognize and inspect particular attributes, which are attached more closely to the outline of repurchases. This study aims to extend the understanding of the development of online repurchase intention within the metrics of consumer's trust, affective commitment, and loyalty in online platforms.

In the competitive global market, it is becoming increasingly notable for the platform to understand the role of trust in sustaining a productive relationship with consumers. However, evolving and upholding trusting relations turn into a testing issue when a social commerce platform needs to develop a confiding association with the consumers or vice versa. Trust has been studied rigorously by many academic scholars [1], [2], [3], and its significance is acknowledged well in e-commerce as well as in social commerce as context [4] [5]. Since, trust is thought to be efficient in predicting the consumer-platform relationship [6], [7], yet most of the previous research has been focused on trust through purchase intentions in social commerce [4], [8] and has been overlooked in measuring the repurchase intentions in social commerce context. Rousseau and Tijoriwala stated that trust is 'a psychological state involving the intention to acknowledge vulnerability dependent on the desires for positive expectations or conduct of another' [9]. It means that the trust of a person in others is influenced by his or her decision on the good intention of the other party. A group that trusts its exchange partner anticipates goodwill to the partner and does not damage the exchange relationship [10]. Hence, trust plays a vital role in defining the consumer-platform relationship, which is defined with the fulfillment of the psychological contract in social commerce.

Psychological contract fulfillment is defined as the degree to which one party (consumer) in a psychological contract believes that the counterparty (social commerce platform) has fulfilled its reciprocal obligation in the relationship of exchange [11]. The fulfillment of such a reciprocal contract is a significant construct for academic researchers and practitioners in social commerce. Most of the researches have been conducted in the employee-organization perspective and has been aimed primarily on the exploration of the significant effect of the fulfillment of psychological contract on commitment and work performance of employees towards their organizations [12], [13]. Since the previous researchers have demonstrated the psychological contracts and their fulfillment to both the positive and negative results of employees in different settings only [14], [15], studying this concept in the consumer-platform relationship is a unique idea. It is of paramount importance to mention that the concept of psychological contract violation has already been well established in the e-commerce literature [16]; this has paved the way for the fulfillment of the psychological contract in the social commerce framework. Therefore, this study refers to the fulfillment of the psychological contract as the degree to which the perceptions of consumer and platform match in social commerce. This research study, unlike most of the previous studies, analyzes the 
presence of limiting circumstances that may influence the psychological contract fulfillment and consumers repurchase intention, loyalty, and affective commitment.

In addition to building a healthy consumer's trust, a social commerce platform should also take specific actions at the time of recruitment, training, and developing employees, that are directly related to consumers, because they are the ones that can make or break the platform in each of their interactions with consumers. Such employees are the major stakeholders in accomplishing the transaction and, consequently, the completion of the provision of the psychological contract relies on crediting staff and sharing values of the platform with its customers. Such responsibilities also imply that the staff must have a high level of empathy so that they can comprehend consumer expectations and respond to their requirements rapidly and efficiently [17]. Despite the emphasis on the crucial role of literature in social interactions, platform interactivity, and platform ethics, most of the research on psychological contract fulfillment neglects the critical importance of employee's empathy. Therefore, in this research, the empathy of the employee is considered and referred to as the platform empathy.

In this research, the investigation of the relationships among consumer trust on platform, platform empathy, psychological contract fulfillment, loyalty, affective commitment, and consumer repurchase intention is intended. This is so to identify whether the trust between a consumer and platform is a necessary input to shape the consumers' perception of psychological contract fulfillment. Besides, this study investigates whether psychological contract fulfillment can explain the effect of trust on consumers' post-purchase behavior or not and how the platform empathy moderates the consumers' trust and psychological contract relationship. Precisely, this study fills the research gap of the relationship between consumers' trust in the platform and consumers' repurchase behavior through psychological contract fulfillment. Methodologically, this relationship is verified with a serial mediation model in which the psychological contract fulfillment mediates the consumers' trust in the platform and post-purchase behavior (affective commitment and consumer loyalty). On the other hand, psychological contract fulfillment and consumer repurchase intention are mediated by affective commitment and consumer loyalty. This study provides some significant theoretical and practical contributions. Theoretically, this research adds to the social exchange theory on whether a high level of consumer trust is an efficient stimulus to initiate the reciprocation of a social exchange process or not. It also contributes to the literature by analyzing whether consumer trust in a platform is an essential condition for the fulfillment of the psychological contract or not and whether this trust offers a salient signal about consumer's satisfaction or dissatisfaction with his or her faith in the psychological contract. Finally, this research talks about the indirect connection between customer trust and consumer intention to repurchase by suggesting and examining a significant, but overlooked, mediating function of the psychological contract fulfillment. In practice, the results of this study apply to strategic design marketing and repurchase, not to mention that the adopted procedures support the dynamics of creating and retaining customer and platform trusting relationships.

In Fig. 1, we summarize our proposition that consumers' trust in the platform will have an effect on consumers' psychological contract fulfillment moderated by platform empathy, which in turn affects their loyalty and affective commitment, ultimately resulting in repurchase intention. 


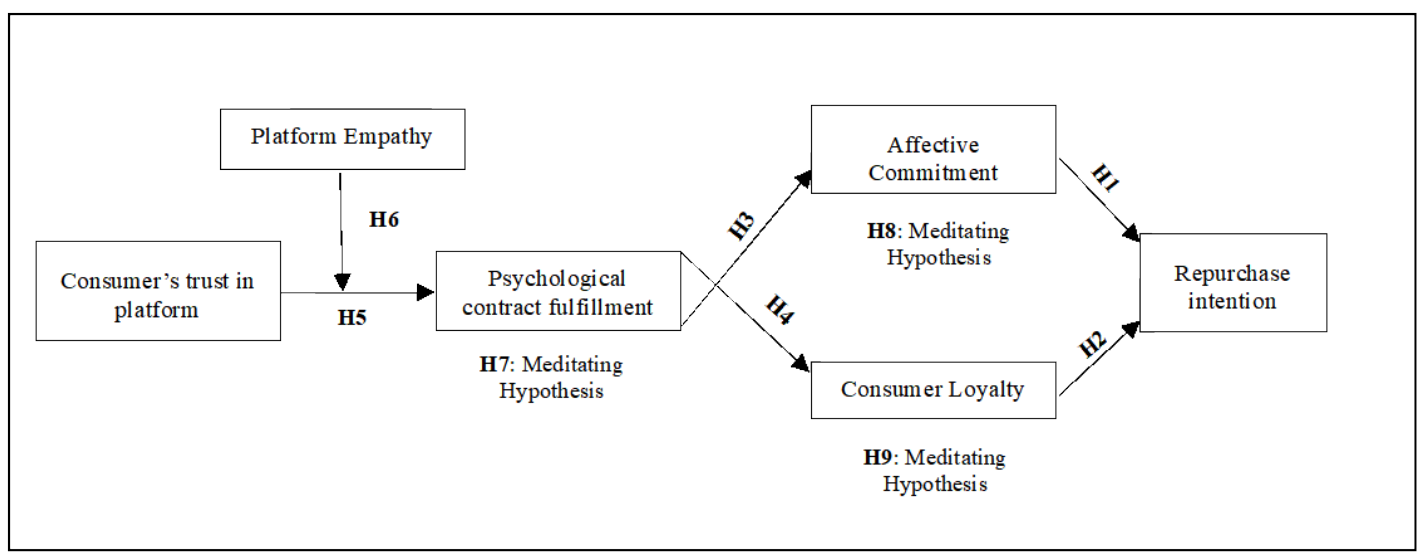

Fig. 1. Proposed Model

\section{Theoretical Background and Hypothesis Development}

\subsection{Affective Commitment and Repurchase Intentions}

Affective commitment is known as a psychological affiliation between consumer and platform along with their persistent wish to continue such association, encouraging both parties to develop and further maintain a trusting and reciprocal relationship [18]. Such affective commitment signifies an overwhelming sense of personal recognition and is deeply rooted in the identification of and sharing values with the brand and platform [19] [20]. In this regard, multitudes of studies constituting existing literature predominantly explain that affective commitment is significantly associated with an individual's purchase intention [21], [22]. To elucidate, consumers having wonderful experiences about the platform are highly likely to formulate their repurchase intentions in the favor of the platform [23]. Thus, we can hypothesize that

H1: Affective commitment has a strong positive association with repurchase intentions.

\subsection{Consumer Loyalty and Repurchase Intention}

Since the cost of obtaining a new consumer is much higher than keeping an old one, therefore, it becomes fundamental for the platform to ensure continuous purchases by the current consumers [23], [24]. Repurchase intention is reflected in the retention of the customer's relationship with the same platform for a next purchase [25]. Repurchase intentions can also be measured and, in other words, defined by the extent of consumer's satisfaction and dissatisfaction in or against the platform [23]. Satisfied consumers have more intentions to buy again from the same platform, as they have strong and positive feelings to that platform [26]. Moreover, consumers who repeatedly buy from a particular vendor or platform are indirectly declared their strong commitment to that specific platform; that is why, they are regarded as loyal consumers [27]. They feel loyal to the platform and help in generating positive word of mouth thus resulting in enhanced repurchase intentions [28]. So, we can hypothesize that

H2: Consumer loyalty has a strong positive association with repurchase intention. 


\subsection{Psychological contract fulfillment and affective commitment}

In argue with social exchange theory (SET), a consumer matches his or her inputs on the platform to the outputs he or she receives so that the consumer is eager to maintain an exchange relationship with a other party even if the consumer receives more than the inputs or perceives mutual reciprocity. Consumers are dedicated to the platform and want to buy back from it when they feel the platform is prepared and able to meet its consumer commitments. Psychological contract fulfillment implies that the platform provides inducements and fulfills its obligations toward consumers. Moreover, psychological contract fulfillment is accomplished when anticipated obligations from the platform and the inducements are offered. Prior literature validates the association between affective commitment and psychological contract perceptions [29]. So, this study claims that psychological contract fulfillment is related to affective commitment because reciprocity exists between consumers and platforms in the social exchange relationship. Coyle-Shapiro and Kessler discovered that employers' psychological contract fulfillment, as perceived by employees, is significantly related to organizational commitment, particularly in transactional and training obligations [14]. Therefore, based on theory and empirical evidence, we can posit that:

H3: Psychological contract fulfillment is significantly associated with affective commitment in a consumer-platform relationship.

\subsection{Psychological contract fulfillment and consumer loyalty}

Psychological contract fulfillment is posited to be positively associated with consumer loyalty. Robinson and Rousseau [30] discovered that psychological contract fulfillment was positively related to an individual's perceptions of how much loyalty he owed. Park and Kidder [31] suggested that extra-role behaviors (performed voluntarily) may be among the first gains of psychological contract fulfillment. Organizations seeking to foster a long-term connection with their staff are more likely to give increased compensation to support trust and loyalty [32]. Supporting this idea, the platform also does the same work on these grounds for attaining consumer loyalty. Robinson and Morrison [15] discovered that consumers who considered their psychological contract had been fulfilled were more likely to participate in optional activities for the sake of the platform [33]-[35]. Therefore, we can hypothesize that psychological contract fulfillment will be positively associated with the readiness of consumers to defend the platform to potential consumers.

H4: The fulfillment of the psychological contract is positively associated with consumer loyalty.

\subsection{Consumer trust on the platform and Psychological contract fulfillment}

Trust is a reflection of consumers' attitudes and behaviors, such as purchase and repurchase intentions [33]-[35], eWOM, and consumer engagement [36]. The consumers' trust in the platform alone is a powerful construct in social commerce, which leads to their post-purchase behavior. It is outlined as the degree to which a consumer believes in the platform in terms of its fulfillment of claimed promises professed to its users [37]. Many prior studies discussed the trust in sheer social-commerce context. For instance, Han and Windsor studied relative causes of trust, and consumers' willingness to pay on social media [34]. Similarly, Ferrin et al. verified the relation between a consumer's trust perception and the platform's co-operative behavior [38]. Some researchers also proposed trust as a critical construct in maintaining consumer-platform relationships through the shared responsibility of 
giving and take [5], [39], [10]. Moreover, social exchange theory indicates that the consumer's voluntary activities, such as purchasing and recommending, are motivated by the degree of trust [40] that they have in the social commerce platform. In other words, such activities of consumers include the decent release of commitments in terms of gaining unspecified future returns, such as services and quality products by the platform, and, later, reciprocating accordingly. Therefore, a strong proposition can be made that, given the amount of trust, the fulfillment of responsibilities by the platform directly related to the consumers' inclination to reciprocate backward, and that is exactly what constitutes the essence of psychological contracts. So, we can hypothesize that:

H5: Consumer trust on the platform is positively related to the psychological contract fulfillment.

\subsection{Moderating Role of Platform Empathy}

In relationship marketing literature, empathy for mutual comprehension and individual consideration between social actors is vital [41]. Especially in online platform setting and services literature, empathy is considered as a significant element for productive platform-consumer communication [42], that mainly leads to understand and counter consumers' thoughts and feelings [43]. Apropos this, different studies confirm that empathy involves two main dimensions: cognitive and emotional [41]. From former that is cognitive standpoint, empathy is platform's potential to undertake consumers viewpoint through understanding of their feelings, intentions, and thoughts [44]. However, from the latter dimension, empathy describes the platform's capability to indulge in positive and helpful actions towards consumers [45].

Several types of research suggest that a platform with an elevated level of empathy can recognize and address the requirements and wishes of consumers more readily [17], thereby it would tend to be more useful in the fulfillment of psychological contracts. When consumers perceive that platform behaves empathetically during interactions, they tend to more favorably evaluate the efficiency of the platform and show more trust in the platform [46]. When consumers perceive that platform behaves empathetically (i.e. attempting to comprehend and address their requirements and wishes) during interactions, they tend to more favorably evaluate the efficiency of the platform and show more trust in the platform [47]. The present study tries to plug this gap by proposing that when the platform behaves in an empathic manner, positive consumer trust in the platform can probably be anticipated, that will turn into an even higher perception of psychological contract fulfillment. According to this reasoning, based on the literature discussed above and concentrating on the consumer's trust in the platform because of its crucial importance in the e-commerce, and specifically in the social commerce context, this study hypothesizes that:

H6: Higher the platform empathy, the stronger the effect of consumer's trust in the perception of psychological contract fulfillment.

\subsection{Mediating Effects of Psychological Contracts fulfillment, consumer loyalty, and affective commitment}

Prior research shows that trust on the platform will lead to repurchase intentions on the proposition that both consumers and platforms have the same intent to acknowledge 
vulnerability, based on each other's expectations of positive behavior [9]. Similarly, trust is established on the expectations that the platform will also do something beneficial in exchange. Since trust plays a crucial role in involving the platform's expectations and reciprocation, consumer's expectations will establish a part of psychological contracts from the consumer's point of view. Rousseau and Parks outlined a psychological contract as individual views formed by the organization as to the terms of an exchange agreement between an individual and their organization [48]. In this study, the platform is an organization, so the platform has to reciprocate according to the expectations of consumers, considering the psychological contract fulfillment that postulates the consumer-platform exchange relationship.

Social exchange theory (SET) elaborates further about psychological contract fulfillment that it is helpful and can lead the impact of trust on consumer repurchase behavior. SET also sheds light on the obligations produced by the interactions of both parties. The psychological contract acts for consumers' perception of the mutual obligations of both consumers and the platform. When consumer trust in the platform is established by undertaking particular responsibility, then consumers are also expecting from the platform to perform reciprocal obligations in return. In a nutshell, consumers believe that both parties have mutual commitments that are interdependent and constitute a psychological contract. Without this trust, consumers will perceive the violation of the psychological contract and retain their reciprocation by showing no further repurchase intention. Based on this discussion, we can hypothesize that:

H7: The consumer's perception of the fulfillment of the psychological contract mediates the effects of trust in the platform on repurchase intentions.

Consumer's trust plays a crucial role in defining attitudes and behaviors, and that is well defined in different studies [31]. Recently, platforms provide consumers more information about products, feedback (ratings), and social support [49] to build their trust in the platform. In doing so, the platform is modeling consumers' perception of showing commitment and loyalty to the platform. Therefore, if consumers trust the platform, they are more confident about the platform that it will adequately meet their conditions of the exchange relationship. Additionally, this will equally create tension for consumers to take action to guarantee a healthy exchange relationship [13]. These kinds of exchange relationships are helpful to generate consumer loyalty and commitments. One plausible step that consumers can take is to enhance their commitment and repurchase intention with the platform. When consumers recognize that their exchange relationship is based on a beneficial social exchange with the platform, these consumers are encouraged to reciprocate by engaging in a repurchase behavior. Therefore, the interdependent responsibilities perceived by consumers will only materialize if both parties trust each other. So, we can hypothesize that:

H8: The consumer's affective commitment mediates the effects of trust in the platform on the consumer's repurchase intentions.

H9: Consumer loyalty mediates the effects of trust in the platform on the consumer's repurchase intentions.

\section{Methodology}

\subsection{Context}

To test the research model, data were collected from Taobao users through a survey. Weitao, a microblogging service in Taobao, gives freedom to vendors to write some articles about their products. This micro-blogging service has both E-commerce as well as social media features; assist our study in justifying the suggested model. 


\subsection{Measurement Development}

Measurement items were tailored from literature, and they were evaluated on a 5-point Likert scale that was ranging from 1 (strongly disagree) to 5 (strongly agree). Sources related to these measures were summed up in an appendix. We had researched in China, so the Chinese language was used in developing the questionnaire. Translation and back-translation technique was implemented to make sure the questionnaire was expressing the same meaning.

\subsection{Pilot Test}

To measure the quality of the questionnaire, a pilot study was conducted. Twenty-five postgraduate and graduate students were involved in this process, having complete knowledge about social commerce. We refined the questions' language and adjusted the questions in the instrument based on the pilot study outcomes. The second round of pilot study was conducted again after revising the instrument. This time pilot study showed satisfactory results that encouraged us that the instrument was ready for data collection.

\subsection{Sample and Procedures}

For data collection, online buyers (taobao.com) were considered as a population of this research. We conducted an online survey and spread the link to different Wechat groups. Most of the groups were related to university students, so these students were the primary sample of this research. Students were the most suitable sample because they are the real users of social media as well as social commerce sites. Due to the unavailability of consumer databases as well as lack of resources, we used non-probability convenient sampling. This study was exploratory because we tried to develop some scales to measure psychological contract fulfillment, consumers' trust in the platform, and platforms' trust in the consumer in social commerce. Table 1 shows all the demographic information about the sample. We got 367 appropriate responses after eliminating 42 unusable responses (missing values and incomplete information).

\section{Data analysis procedures}

For data analysis, Smart PLS version 3.0 was used. To test the relationships between the proposed hypotheses, partial least square based structural equation modeling (PLS-SEM) was used.

Table 1. Demographics of Respondents

\begin{tabular}{llll}
\hline \multicolumn{1}{c}{ Demographics } & & Frequency & Percentage \\
\hline Gender & Male & 192 & $52.3 \%$ \\
\multirow{3}{*}{ Marital Status } & Female & 175 & $47.7 \%$ \\
\multirow{3}{*}{ Age } & Single & 285 & $77.6 \%$ \\
& Married & 82 & $22.4 \%$ \\
& $18-22$ & 175 & $47.7 \%$ \\
& $23-27$ & 118 & $32.1 \%$ \\
& $28-32$ & 34 & $9.3 \%$ \\
& $33-37$ & 15 & $4.1 \%$ \\
& $38-42$ & 12 & $3.3 \%$
\end{tabular}




\begin{tabular}{|c|c|c|c|}
\hline \multirow{3}{*}{ Frequency of Use } & Equal to or above 43 & 13 & $3.5 \%$ \\
\hline & Once a day & 298 & $81.2 \%$ \\
\hline & Once a week & 41 & $11.2 \%$ \\
\hline \multirow[b]{5}{*}{ Education } & Once a month & 21 & $5.7 \%$ \\
\hline & Semi-annually & 7 & $1.9 \%$ \\
\hline & Bachelor & 151 & $41.2 \%$ \\
\hline & Master & 169 & $46.0 \%$ \\
\hline & Ph.D. and above & 47 & $12.8 \%$ \\
\hline \multirow{5}{*}{$\begin{array}{l}\text { Monthly } \\
\text { Income }\end{array}$} & $\leq 3000 \mathrm{RMB}$ & 231 & $62.9 \%$ \\
\hline & 3000-3999 RMB & 71 & $19.4 \%$ \\
\hline & 4000-4999 RMB & 35 & $9.5 \%$ \\
\hline & 5000-5999 RMB & 26 & $7.1 \%$ \\
\hline & $\geq 6000 \mathrm{RMB}$ & 4 & $1.1 \%$ \\
\hline
\end{tabular}

\subsection{Analysis and results of the measurement model}

Reliability and validity of the measurement model: This study assessed the psychometric proprieties (i.e., reliability, convergent, and discriminant validity) of all six constructs used in this study. Reliability is defined to measure the overall consistency of the instrument [50]. Higher the reliability of the instrument represents that the instrument will generate similar results under consistent conditions. The reliability $(\alpha)$ for each construct was found to range from 0.874 to 0.927 is presented in Table 2, which exceeds the suggested level of 0.70 . The next metric that is used in this study is Composite reliability (CR) that works as an alternate to Cronbach's alpha. In a reflective model, CR is used to test the convergent validity. CR is also a preferred way to measure the reliability over Cronbach's alpha because Cronbach's alpha may over or underestimate scale reliability [51]. As shown in Table 2, CR for all constructs ranged from 0.851 to 0.945 - more significant than the cut-off level of 0.70 , as suggested by Hair Jr. et al. [52], confirming the convergent validity of the model. Besides, average extracted variance (AVE) is used to test convergent and divergent validity. In a reflective model, AVE reveals the average communality for each latent factor [53]. AVE ranged from 0.542 to 0.772 for all constructs, which was more significant than 0.50 [54].

Table 2. AVE and Reliability

\begin{tabular}{lclll}
\multicolumn{1}{c}{ Constructs } & $\begin{array}{l}\text { Cronbach } \\
\text { Alpha }\end{array}$ & Rho_A & $\begin{array}{l}\text { Composite } \\
\text { Reliability }\end{array}$ & AVE \\
\hline Commitment & 0.902 & 0.904 & 0.931 & 0.772 \\
Loyalty & 0.874 & 0.877 & 0.914 & 0.727 \\
$\begin{array}{l}\text { PC Fulfillment } \\
\text { Repurchase }\end{array}$ & 0.912 & 0.929 & 0.932 & 0.734 \\
Intentions & 0.927 & 0.929 & 0.945 & 0.776 \\
Trust & 0.881 & 1.284 & 0.851 & 0.542 \\
Empathy & 0.901 & 0.91 & 0.931 & 0.770 \\
\hline
\end{tabular}


All the constructs in the instrument should not be highly related to each other and are referred to as Discriminant validity [55]. According to Fornell and Larcker's criterion [54], the discriminating validity of the factors incorporated in the measurement model was also examined by the fact that the square root of the average variance extracted for each construct was higher than the square of the inter-construct correlations (see Table 3).

Table 3. The result of discriminant validity

\begin{tabular}{lllllll}
\hline Constructs & AC & CL & PCF & RI & CT & PE \\
\hline AC & 0.879 & & & & & \\
CL & 0.556 & 0.853 & & & & \\
PCF & 0.293 & 0.388 & 0.857 & & & \\
RI & 0.661 & 0.536 & 0.292 & 0.881 & & \\
CT & 0.593 & 0.371 & 0.212 & 0.596 & 0.801 & \\
PE & 0.556 & 0.507 & 0.407 & 0.540 & 0.359 & 0.878 \\
\hline
\end{tabular}

$\mathrm{AC}=$ Affective commitment, $\mathrm{CL}=$ Consumer loyalty, $\mathrm{PCF}=$ Psychological contract fulfillment, $\mathrm{RI}=$ Repurchase Intention, $\mathrm{CT}=$ Consumer trust on platform, Platform Empathy=PE

Besides, as proposed by Henseler et al. [56], the HTMT correlation ratio was also calculated. It is a contemporary instrument used to evaluate the legitimacy of discrimination. According to Henseler et al., HTMT's highest acceptable value for confirming discriminant validity is 0.85 , while any above value indicates a validity issue [56]. The comprehensive findings of the HTMT evaluation are given in Table 4.

Table 4. Discriminant Validity (HTMT)

\begin{tabular}{llllll}
\hline & Commitment & Loyalty & $\begin{array}{l}\text { PC } \\
\text { Fulfillment }\end{array}$ & $\begin{array}{l}\text { Repurchase } \\
\text { Intentions }\end{array}$ & Trust empathy \\
\hline $\begin{array}{l}\text { Commitment } \\
\text { Loyalty }\end{array}$ & 0.625 & & & & \\
$\begin{array}{l}\text { PC } \\
\text { Fulfillment }\end{array}$ & 0.317 & 0.419 & & & \\
$\begin{array}{l}\text { Repurchase } \\
\text { Intentions }\end{array}$ & 0.602 & 0.592 & 0.315 & & \\
Trust & 0.669 & 0.406 & 0.123 & 0.682 & \\
empathy & 0.612 & 0.504 & 0.425 & 0.585 & 0.39 \\
\hline
\end{tabular}

Furthermore, the variance inflation factor (VIF) was assessed regarding all variables. The VIF evaluates the severity of multicollinearity, and Smart PLS 3.0 has some vital features to estimate the collinearity. Petter et al. [57] expressed that the VIF value should be less than 3.3 to overcome multicollinearity, and all variables showed values less than cut-off values 3.3.

Common Method Variance Estimations: Data was gathered through a single source, and it was cross-sectional, so Harman's single-factor analysis was used to check the common method variance (CMV) estimations [58]. Spurious covariance shared among variables has been tested since a common method is used in data collection. An exploratory factor analysis of all constructs' items revealed that the first two factors cumulatively account for $40.988 \%$ of 
the variance, with the first factor accounting for $34.613 \%$ and the second factor explaining $6.375 \%$ of the total variance. The single factor did not account for the majority of the variance, which indicates that the common method bias does not affect the data.

\subsection{Structural Model Analysis}

This study examined the trust, psychological contract, and consumer behaviors in social commerce. Collected data was used to test hypotheses, and path coefficients are elaborated. A path coefficient shows the direct effect of one variable is supposed to be a cause on another variable that is supposed to be an effect. Path coefficients are assessed from correlations, so they are standardized whereas the coefficient of path regression is unstandardized [59]. Table 5 presents the results of the structural equation modeling using PLS concerning the proposed model.

Table 5. Path coefficients

\begin{tabular}{lccccc}
\hline Relationships & $\begin{array}{c}\text { Original } \\
\text { Mean }\end{array}$ & $\begin{array}{c}\text { Sample Mean } \\
(\mathbf{M})\end{array}$ & STDEV & T Statistics & P-value \\
\hline AC $\rightarrow$ RI & 0.960 & 0.959 & 0.018 & 53.092 & 0.000 \\
CL $\rightarrow$ RI & 0.410 & 0.401 & 0.032 & 12.843 & 0.001 \\
PCF $\rightarrow$ AC & 0.293 & 0.294 & 0.098 & 2.992 & 0.003 \\
PCF $\rightarrow$ CL & 0.387 & 0.391 & 0.111 & 3.490 & 0.001 \\
CT $\rightarrow$ PCF & 0.714 & 0.710 & 0.040 & 17.851 & 0.000 \\
\hline
\end{tabular}

The association between affective commitment and intention to repurchase was significant and positive (coefficient $=0.960, t=53.092$ ). As a result, $\mathrm{H} 1$ was supported. Consumer loyalty had a significant impact on repurchase intention; the relationship was significant (coefficient $=0.410, t=12.843$ ). Thus, $\mathrm{H} 2$ was supported. H3 was also validated because the association between affective commitment and psychological contract fulfillment was significant and positive (coefficient $=0.293, \mathrm{t}=2.992$ ). Consumer loyalty was positively influenced by psychological contract fulfillment in social commerce sites at $p=0.000$ (coefficient=0.387, $\mathrm{t}=3.490$ ). Thus, $\mathrm{H} 4$ was supported. The relationship between trust and psychological contract fulfillment was significant at $\mathrm{p}=0.000$ (coefficient $=0.714, \mathrm{t}=17.851$ ). Thus, H5 was supported as expected. Fig. 2 explained the results described above.

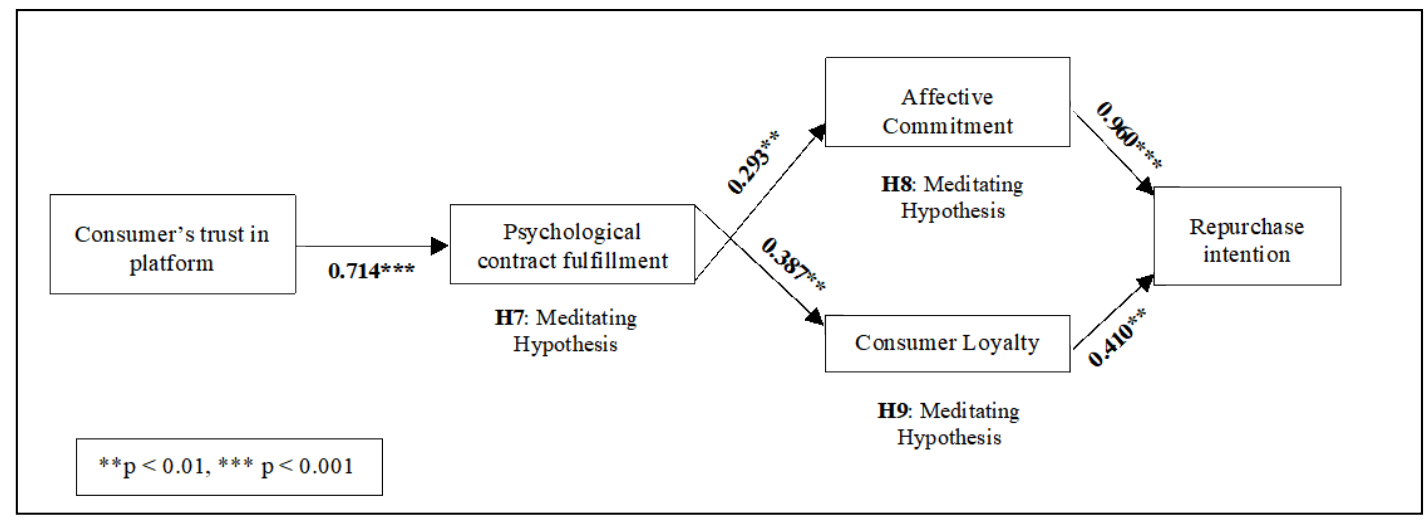

Fig. 2. Structural Model results 


\subsection{Moderating Effects of Platform Empathy}

In Fig. 3, we describe the evaluation of moderation using the PLS product-indicator approach (Chin et al., 2003) to detect the moderating impact of platform empathy on the connection between consumer trust in the platform and psychological contract fulfillment. To test the likelihood of such an impact, consumer trust in the platform (predictor) and platform empathy (moderator) multiplied to produce an interaction term (consumer trust $\times$ Platform empathy) to predict the fulfillment of psychological contracts [60], [61]. In this situation, platform empathy consists of four items, and customer trust consists of seven items, so the interaction term represents 28 items $(4 \times 7)$. This interaction variable's AVE and CR are respectively 0.657 and 0.893 , which surpass the minimum value of the cut-off.

First, we estimated the impact of consumer trust in the fulfillment of psychological contracts to test the moderating impact. Second, the immediate effect of platform empathy on the fulfillment of psychological contracts and then the influence of interaction construct on the fulfillment of psychological contracts were assessed. Where the interaction effect is significant, the importance of a moderator can be verified regardless of the size of the other associated path coefficients [60]. In this situation, we calculated a standardized path coefficient of 0.364 for the interaction construct, which was significant at $\mathrm{p}<0.01(\mathrm{t}=2.101)$. In evaluating the significance of the interaction effect, we used a two-tailed test due to a lack of theoretical assistance on whether platform empathy increases or decreases the link between consumer confidence in the platform and psychological contract fulfillment [62].

The effect size is calculated as follows: $f^{2}=\frac{R_{i}^{2}-R_{m}^{2}}{1-R_{i}^{2}}$

Where, $i=$ interaction model, and $m=$ main effect model

The findings demonstrate a medium magnitude of the moderating impact $\left(\mathrm{f}^{2}=0.17\right)$ [63] as well as the resulting beta shifts $(\beta=0.364, t=2.101)$ are significant. Results, therefore, verified that platform empathy moderates the connection between consumer trust in the platform and psychological contract fulfillment, and we accepted H6 (see Fig. 3).

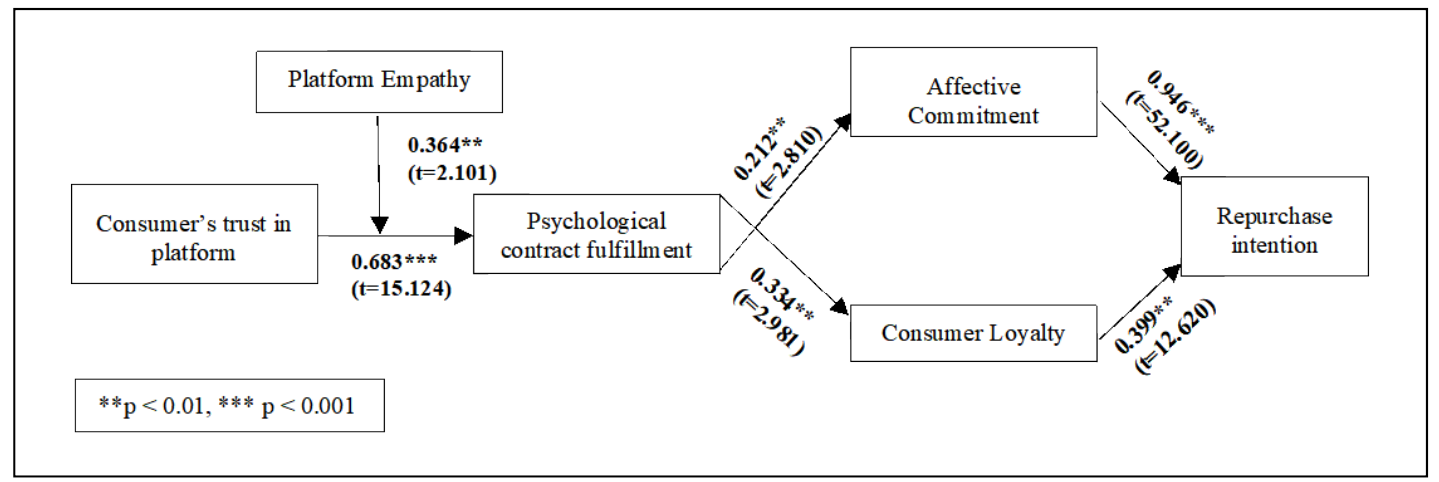

Fig. 3. Moderation Results 


\subsection{Mediating Effects of Psychological Contract Fulfillment, Affective commitment, and consumer loyalty}

To test for mediation, we employed the latest conventions [64], [65], [66] focused on bootstrapping. To verify the mediation role of psychological contract fulfillment, affective commitment, and consumer loyalty, this study suggested Baron and Kenny approach and tested the hypothesis H7, H8, and H9. To determine the mediating effect, the indirect effect must be significant [67]. After analyzing the model, we found that consumer trust in the platform had a significant effect on psychological contract fulfillment, which in line has a robust relation with repurchase intentions. The indirect effects of consumer trust on the platform through the psychological contract fulfillment were both significant. Similarly, consumer trust in the platform has a significant effect on consumer loyalty and affective commitment; having a robust relationship with repurchase intentions. The indirect effect is calculated by multiplying the indirect effect through the mediator, to evaluate the magnitude of the indirect effect. This research calculated Variance Accounted For (VAF), which determines the magnitude of the indirect effect with the total effect (VAF = Indirect effect / Total effect). When VAF value lies from $20 \%$ to $80 \%$, a partial mediation can be anticipated, and the value exceeding $80 \%$ means full mediation exists [52]. Table 6 explained the results of all three mediating hypotheses.

Table 6. Mediation Effects

\begin{tabular}{|c|c|c|c|c|c|c|c|c|c|c|c|}
\hline Hypothesis & Procedure & Path & $\begin{array}{l}\text { Path } \\
\text { Coef. }\end{array}$ & $\begin{array}{l}\text { Indirect } \\
\text { Effects }\end{array}$ & STDEV & $\begin{array}{l}\text { Total } \\
\text { Effects }\end{array}$ & VAF & $\begin{array}{l}\text { t } \\
\text { Values }\end{array}$ & $\begin{array}{l}\text { Sig. } \\
\text { level }\end{array}$ & $\begin{array}{l}\text { P-va } \\
\text { lue }\end{array}$ & Results \\
\hline \multirow{4}{*}{ H7 } & $\begin{array}{l}\text { Step 1: Direct Effect } \\
\text { (Without mediator) }\end{array}$ & $\mathrm{CT} \rightarrow \mathrm{RI}$ & 0.63 & & $\mathrm{n} / \mathrm{a}$ & & & 13.018 & $* * *$ & 0 & \\
\hline & \multirow{3}{*}{$\begin{array}{l}\text { Step 2: Indirect effect } \\
\text { (with a mediator) }\end{array}$} & $\mathrm{CT} \rightarrow \mathrm{RI}$ & 0.416 & & & & & & & & Accepted \\
\hline & & $\mathrm{CT} \rightarrow \mathrm{PCF}$ & 0.577 & \multirow{2}{*}{0.141} & \multirow{2}{*}{0.028} & 0.557 & 0.253 & 5.036 & $* * *$ & 0 & \\
\hline & & $\mathrm{PCF} \rightarrow \mathrm{RI}$ & 0.244 & & & & & & & & \\
\hline \multirow{4}{*}{ H8 } & $\begin{array}{l}\text { Step 1: Direct Effect } \\
\text { (Without mediator) }\end{array}$ & $\mathrm{CT} \rightarrow \mathrm{RI}$ & 0.688 & & $\mathrm{n} / \mathrm{a}$ & & & 7.512 & $* * *$ & 0 & \\
\hline & \multirow{3}{*}{$\begin{array}{l}\text { Step 2: Indirect effect } \\
\text { (with mediator) }\end{array}$} & $\mathrm{CT} \rightarrow \mathrm{RI}$ & 0.539 & & & \multirow{3}{*}{0.691} & \multirow{3}{*}{0.220} & \multirow{3}{*}{3.435} & \multirow{3}{*}{$* *$} & \multirow{3}{*}{$\begin{array}{c}0.00 \\
1\end{array}$} & Accepted \\
\hline & & $\mathrm{CT} \rightarrow \mathrm{AC}$ & 0.404 & \multirow{2}{*}{0.152} & \multirow{2}{*}{0.004} & & & & & & \\
\hline & & $\mathrm{AC} \rightarrow \mathrm{RI}$ & 0.377 & & & & & & & & \\
\hline \multirow{4}{*}{ H9 } & $\begin{array}{l}\text { Step 1: Direct Effect } \\
\text { (Without mediator) }\end{array}$ & $\mathrm{CT} \rightarrow \mathrm{RI}$ & 0.701 & & $\mathrm{n} / \mathrm{a}$ & & & 14.211 & $* * *$ & 0 & \multirow{4}{*}{ Accepted } \\
\hline & \multirow{3}{*}{$\begin{array}{l}\text { Step 2: Indirect effect } \\
\text { (with a mediator) }\end{array}$} & $\mathrm{CT} \rightarrow \mathrm{RI}$ & 0.551 & \multicolumn{2}{|c|}{$\mathrm{n} / \mathrm{a}$} & \multirow{3}{*}{0.784} & \multirow{3}{*}{0.297} & \multirow{3}{*}{9.203} & \multirow{3}{*}{$* * *$} & \multirow{3}{*}{0} & \\
\hline & & $\mathrm{CT} \rightarrow \mathrm{CL}$ & 0.676 & \multirow{2}{*}{0.233} & \multirow{2}{*}{0.079} & & & & & & \\
\hline & & $\mathrm{CL} \rightarrow \mathrm{RI}$ & 0.345 & & & & & & & & \\
\hline
\end{tabular}




\subsection{The goodness of Fit (GoF)}

While PLS-SEM does not produce overall Goodness of Fitness (GoF) indices, the value of $\mathrm{R}^{2}$ is considered the primary way of assessing the model's explanatory power [56]. Tenenhaus et al. [68] described the GoF index, a diagnostic tool, to evaluate the model fit. GoF is determined by using the geometric mean value of the average community score (AVE scores) and the average $R^{2}$ values (for endogenous constructs) and estimated using the following formula $\left(\mathrm{GoF}=\sqrt{ }\left(\mathrm{AVE} \times \mathrm{R}^{2}\right)\right.$. Tenenhaus et al. [68] didn't reported any cut-off values for GoF index; but Wetzels et al. explained following cut-off values to evaluate GoF analysis: $\mathrm{GoF}_{\text {small }}=0.1 ; \mathrm{GoF}_{\text {medium }}=0.25 ; \mathrm{GoF}_{\text {large }}=0.36$ [69]. According to Henseler et al. [56], a good model fit indicates that a model is parsimonious and plausible. Keeping in mind the guidelines of Tenenhaus et al. [68] and Henseler et al. [56], the GoF index was determined for the model included in this analysis, as shown in Table 7. As shown in the table below, a conceptual model used in this analysis yielded an index value of 0.485 for GoF, suggesting a perfect model fit.

Table 7. Goodness of Fit

\begin{tabular}{lll}
\hline Constructs & AVE & $\mathbf{R}^{2}$ \\
\hline Trust & 0.542 & \\
Empathy & 0.770 & \\
PC Fulfilment & 0.734 & 0.228 \\
Loyalty & 0.727 & 0.150 \\
Commitment & 0.772 & 0.206 \\
Repurchase Intentions & 0.776 & 0.724 \\
\hline Average Scores & 0.720 & 0.327 \\
AVE * R2 & 0.235 & \\
GoF $=\sqrt{ }\left(\mathrm{AVE} \times \mathrm{R}^{2}\right)$ & $\mathbf{0 . 4 8 5}$ & \\
\hline
\end{tabular}

\section{Discussion}

The present conceptual model is primarily constructed to analyze repurchase intentions through psychological contract fulfillment in social commerce sites. The followings are the key findings of this study.

First, our findings demonstrate that consumers' trust in the platform is a critical variable that highly increases the psychological contract fulfillment in social commerce context. When consumers visit any social commerce site, they get plenty of knowledge and information through ratings and reviews, which increase/decrease their level of trust on that particular platform. If they have a high level of trust on the platform, they feel and perceive that the platform will fulfill their psychological contracts in all means. Trust is considered as a primary construct in building a consumer-platform relationship [5], [39], and demonstrates that the trustor collaborative conduct influences the other party as well [10]. Prior studies also describe that trust is used to value the relationship that includes mutual understanding and has more reciprocal obligations [16] that is the primary condition for psychological contract fulfillment. The fruitful financial or value exchanges build consumers' trust in the platform and also motivate consumers to the completion of the psychological contract. The different level of commitments by the platforms to their consumers play an essential role in determining that to which extent the consumers would share information about products, thus fulfilling the spirit of the psychological contract. Due to the high level of platform's commitment, the consumers 
are encouraged to reciprocate, in return to the trust they have built for the platform, in the form of repurchase intentions.

Second, this study verifies that psychological contract fulfillment has a positive and significant relationship with consumer loyalty and affective commitment. When consumers feel that the platform has fulfilled its psychological contracts, then they try to reciprocate in terms of loyalty and commitment. This study proves the results of previous research that shows that psychological contract fulfillment is positively associated with an individual's perceptions of how much loyalty and commitment he/she owes [29], [30].

Third, this research further validates that consumer loyalty and affective commitment have a significant relationship with repurchase intentions. When consumers feel that the platform is good enough to fulfill all its psychological obligations, then consumers are also loyal to that platform. Prior research demonstrated that loyal consumers choose the same social commerce platform and repurchase again from the same platform [70]. Furthermore, several studies also clarify that affective commitment as profound likeness to specific platforms that helps to enhance repurchase intentions [21- 22]. In China, consumers have deep affection about platforms like Taobao and JD, and that affections lead them to purchase and repurchase intentions.

Fourth, the results of the present study show that the fulfillment of the psychological contract is a significant and partial mediator between the consumers' trust in the platform and their repurchase intention. Psychological contract fulfillment helps to enhance repurchase intentions that are possible when consumers show trust in the social commerce platform. The fulfillment of psychological contract also mediates the relationship between trust and task performance in previous studies that are conducted in the human resource management context [11]. Moreover, consumer loyalty and affective commitment also mediate the relationship between consumers' trust and repurchase intentions, which is shown in this research. These two constructs are considered significant in marketing and online commerce research that are also helping marketers and online platforms to gain sales and profits by retaining actual consumers. Besides, we found that platform empathy, a moderating variable, plays its role in mediating the trust-psychological contract fulfillment relationship. When the platform is eager to provide all the necessary information to consumers in a positive and well-defined way, then consumers show a high level of trust on the platform, resulting in the perception that their psychological contract is also fulfilled. Consumers feel that the platform is providing them guidance, information, and help that they need and generate the perception that the platform is performing its obligations.

\subsection{Theoretical contribution}

The present research extends past research on trust in the following scenario; this is the pioneer study in revealing the psychological contract fulfillment as a missing, but significant mediator between consumers' degree of trust on the platform and their repurchase behavior. This study has made four theoretical contributions. First, the findings of this study add to the social exchange theory that a recipient will be reciprocated not only based on the amount of goodwill that he/she feels toward the donor but also on a high convergence in the trust between the donor and the recipient. Second, our results contribute to an understanding of the attribution theory. When the consumers understand why and how excellently the platform provides informational and emotional support [49], they are likely to attribute the cause of such provision to the trust that they build for the platform, which thus shapes their future buying behavior. This way, the consumer and platform mutually regard the spirit of the psychological contract. Third, the findings contribute to the literature of social commerce by 
providing an empirical test and finding that it is likely that consumer trust exerts an indirect impact on consumers' post behavior. Finally, our study contributes generally to the literature of the psychological contract in that trust between platform and consumers are found to be a salient predictor of the fulfillment of the psychological contract. It also develops and strengthens the relationship between trust and consumers' repurchase intention, loyalty, and commitment. In addition to this, our findings also enrich the work of Cheung et al. and Lee et al. [11], [13], by theoretically integrating the trust and psychological contract literature in social commerce sites.

\subsection{Practical implications}

Our results propose the subsequent implications for platform and marketers. Focusing on the significant role performed by psychological contract fulfillment as a mediator in the trusted environment, marketers and platform are stimulated to begin reciprocal trust through constructing and sustaining a successful psychological contract. First, the platform should permit consumers by providing them a conversation platform to disclose their needs and wants during the transaction and also identify the mutual commitments of both sides (consumer and online shop). Second, the platform is also motivated to create and encourage a trustworthy atmosphere that enables customers to deal constructively with disagreements about their anticipated commitments.

Communications between consumers and platform are the most significant part that helps in fulfilling their commitment and also helpful in psychological contract fulfillment. For building trust on the platform, the platform's commitment may be shown by providing a benefit package. Benefits package may include something extra that consumer is not expecting and it works as an initiative to build trust. Third, the platform can inspire consumers to report any psychological contract fulfillment issues.

Besides taking care of psychological contracts, the platform can promote its trustworthiness by publicly exchanging opinions and increasing investment in consumer development. Psychological contract fulfillment is the best way for marketers and the platform to earn consumer loyalty, commitment, and repurchase intentions. Acquiring a new consumer is much more expensive than keeping an old one. So, the fulfillment of psychological contract helps to retain the old consumers and maintain their consumer behavior. Platform empathy can be an excellent source to retain old consumers by winning their trust in the platform. As well, the platform can promote consumers' trust by promising consumers to share their thoughts, emotions, and expectations freely.

\subsection{Limitations and future research}

First, consumers' trust in the platform, psychological contracts, and consumer behavior are scored by consumers that are associated with that platform. Future research may attempt to add platform trust to consumers, and this construct can be measured by platform personnel. Second, the sample is collected in China, so more pieces of evidence are needed to validate and generalize this model in other environments. Taobao, a social commerce site, is used to analyze this model. Other social commerce sites like Facebook, Twitter and Pinterest can also be used for future research to cross-validate the findings. Finally, data is gathered for this study is cross-sectional. The researchers can further examine the trust and loyalty level of the consumer by gathering longitudinal data. It is quite interesting that a high level of trust in the platform will lead to higher psychological contract fulfillment and vice versa. These results open a new debate to study about a lower level of psychological contract fulfillment or 
psychological contract violations in social commerce. Future studies may also consider exploring consumers' perceptions of psychological contract violations in social commerce and their impact on purchase and repurchase intentions. The researcher may also keep the cultural dimensions in their mind for future work because culture can be an essential construct to study in psychological contract fulfillment. Future research can try to gather consumers' post-purchase behavioral data from other sources like platform records or some secondary databases using data-driven analysis.

\section{Conclusion}

This research extends the available literature on trust and psychological contract by proving that the psychological contract fulfillment facilitates the trust between consumers and platforms to enhance consumers' repurchase intention, consumer loyalty, and affective commitment. The results sufficiently show that psychological contract fulfillment partially mediates the consumer's trust in the platform and consumers' repurchase behavior relationship. This outcome opens up a fresh avenue of studies into this significant but mainly overlooked part of psychological contracts and trust in social commerce studies.

\section{Acknowledgement}

The research work presented in this paper was funded by the Natural Science Foundation of China under Grant no. 71431002 and 71731003.

\section{References}

[1] E. Bonsón Ponte, E. Carvajal-Trujillo, and T. Escobar-Rodríguez, "Influence of trust and perceived value on the intention to purchase travel online: Integrating the effects of assurance on trust antecedents,” Tour. Manag., vol. 47, pp. 286-302, 2015. Article(CrossRef Link)

[2] J. de A.-S. C. M. Nadeem Faisal, Martin Gonzalez-Rodriguez, Daniel Fernandez-Lanvin, "Web Design Attributes in Building User Trust, Satisfaction, and Loyalty for a High Uncertainty Avoidance Culture,” IEEE Trans. HUMAN-MACHINE Syst., vol. 47, no. 6, pp. 847-859, 2017. Article(CrossRef Link)

[3] S. (Fone) Pengnate and R. Sarathy, "An experimental investigation of the influence of website emotional design features on trust in unfamiliar online vendors," Comput. Human Behav., vol. 67, pp. 49-60, 2017. Article(CrossRef Link)

[4] W. S. Chow and S. Shi, "Understanding Consumer Trust in Social Commerce Websites,” in Proc. of Pacific Asia Conference on Information Systems (PACIS) 2014 Proceedings, 2014, pp. 1-19. Article(CrossRef Link)

[5] B. Lu, W. Fan, and M. Zhou, "Social presence, trust, and social commerce purchase intention: An empirical research,” Comput. Human Behav., vol. 56, pp. 225-237, 2016. Article(CrossRef Link)

[6] A. Wongkitrungrueng and N. Assarut, "The role of live streaming in building consumer trust and engagement with social commerce sellers,” J. Bus. Res., 2018. Article(CrossRef Link)

[7] R. P. J. Kingshott and A. Pecotich, "The impact of psychological contracts on trust and commitment in supplier-distributor relationships,” Eur. J. Mark., vol. 41, no. 9-10, pp. 10531072, 2007. Article(CrossRef Link)

[8] N. Hajli, "Social commerce constructs and consumer's intention to buy,” Int. J. Inf. Manage., vol. 35, no. 2, pp. 183-191, 2015. Article(CrossRef Link) 
[9] D. M. Rousseau and S. a Tijoriwala, “Assessing psychological contracts: Issues, alternatives and measures,” J. Organ. Behav., vol. 19, no. 7, pp. 679-695, 1998. Article(CrossRef Link)

[10] D. Hannah, E. Treen, L. Pitt, and P. Berthon, "But you promised! Managing consumers' psychological contracts,” Bus. Horiz., vol. 59, no. 4, pp. 363-368, 2016. Article(CrossRef Link)

[11] C. Lee, J. U. N. Liu, D. M. Rousseau, C. Hui, and Z. X. Chen, "INDUCEMENTS, CONTRIBUTIONS, AND FULFILLMENT IN NEW EMPLOYEE PSYCHOLOGICAL CONTRACTS,” Hum. Resour. Manag., vol. 50, no. 2, pp. 201-226, 2011.

Article(CrossRef Link)

[12] S. H. Kim, G. Laffranchini, M. F. Wagstaff, and W. Jeung, "Psychological contract congruence, distributive justice, and commitment,” J. Manag. Psychol., vol. 32, no. 1, pp. 45-60, 2017. Article(CrossRef Link)

[13] M. F. Cheung, C. S. Wong, and G. Y. Yuan, "Why mutual trust leads to highest performance: The mediating role of psychological contract fulfillment,” Asia Pacific J. Hum. Resour., vol. 55, pp. 430-453, 2017. Article(CrossRef Link)

[14] J. A. M. Coyle-Shapiro and I. Kessler, "Consequences of the psychological contract for the employment relationship: a large scale survey,” J. Manag. Stud., vol. 37, no. 7, pp. 903-930, 2000. Article(CrossRef Link)

[15] S. L. Robinson and E. W. Morrison, "Psychological contracts and organisational citizenship behaviour: The effects of unfulfilled obligations on civic virtue brhavior," J. Organ. Behav., vol. 16, pp. 289-298, 1995. Article(CrossRef Link)

[16] P. A. Pavlou and D. Gefen, "Psychological contract violation in online marketplaces: Antecedents, consequences, and moderating role,” Inf. Syst. Res., vol. 16, no. 4, pp. 372-399, 2005. Article(CrossRef Link)

[17] C. Homburg, J. Wieseke, and T. Bornemann, "Implementing the marketing concept at the employee-customer interface: The role of customer need knowledge,” J. Mark., vol. 73, no. 4, pp. 64-81, 2009. Article(CrossRef Link)

[18] E. S. T. Wang and M. C. Tsai, "Effects of the perception of traceable fresh food safety and nutrition on perceived health benefits, affective commitment, and repurchase intention," Food Qual. Prefer., vol. 78, pp. 1-7, 2019. Article (CrossRef Link)

[19] H. Shahbaz, Y. Li, W. Li, and M. Ali, "Psychological Contracts, Antecedents and Consequences: A New Roadmap to Enhance Purchase Intentions in Social Commerce," in Proc. of Australasian Conference on Information Systems, pp. 1-8, 2017. Article (CrossRef Link)

[20] I. Pring, "Forum - Going underground: How ethngraphy helped the tube tunnel to the heart of its brand,” Int. J. Mark. Res., vol. 49, no. 6, pp. 693-705, 2007. Article (CrossRef Link)

[21] S. Raju, "Positive and negative effects of affective and continuance brand commitment in a service context,” J. Indian Bus. Res., vol. 9, no. 2, pp. 133-148, 2017. Article (CrossRef Link)

[22] Chih, W. H., D. K. Liou, and L. C. Hsu, "From positive and negative cognition perspectives to explore e-shoppers' real purchase behavior: An application of tri- component attitude model,” Inf. Syst. E-bus. Manag., vol. 13, no. 3, pp. 495-526, 2015. Article (CrossRef Link)

[23] L. J. Liang, H. C. Choi, and M. Joppe, "Exploring the relationship between satisfaction, trust and switching intention, repurchase intention in the context of Airbnb,” Int. J. Hosp. Manag., vol. 69, no. September 2016, pp. 41-48, 2018. Article (CrossRef Link)

[24] K. Menon and C. Ranaweera, "Beyond close vs. distant ties: Understanding post-service sharing of information with close, exchange, and hybrid ties,” Int. J. Res. Mark., vol. 35, no. 1, pp. 154-169, 2018. Article (CrossRef Link)

[25] Y. W. Sullivan and D. J. Kim, “Assessing the effects of consumers' product evaluations and trust on repurchase intention in e-commerce environments,” Int. J. Inf. Manage., vol. 39, pp. 199-219, 2018. Article (CrossRef Link)

[26] I. D. Savila, R. N. Wathoni, and A. S. Santoso, “The Role of Multichannel Integration , Trust and Offline-to-Online Customer Loyalty Towards Repurchase Intention : an Empirical Study in Online-to-Offline ( O2O ) e-commerce,” Procedia Comput. Sci., vol. 161, pp. 859-866, 2019. Article (CrossRef Link) 
[27] A. A. Baldinger and J. Rubinson, "Brand Loyalty: The link between attitude and behavior,” $J$. Advert. Res., vol. 36, no. 6, pp. 22-34, 1996. Article (CrossRef Link)

[28] R. Frooghi and Z. Rashidi, "Does Value Co-creation impacts Customer Loyalty and Repurchase Intention ?,” IBT J. Bus. Stud., vol. 15, no. 1, pp. 1-18, 2019. Article (CrossRef Link)

[29] T. A. Birtch, F. F. Chiang, and E. Van Esch, "A social exchange theory framework for understanding the job characteristics-job outcomes relationship: the mediating role of psychological contract fulfillment,” Int. J. Hum. Resour. Manag., vol. 27, no. 11, pp. 12171236, 2016. Article (CrossRef Link)

[30] S. L. Robinson, D. M. Rousseau, S. Journal, N. May, and S. L. Robinson, "Violating the Psychological Contract,” J. Organ. Behav., vol. 15, no. 3, pp. 245-259, 1994.

Article(CrossRef Link)

[31] J. M. Parks and D. L. Kidder, “'Till Death Us Do Part...' Changing Work Relationships in the 1990s,” J. Organ. Behav., vol. 1, 1994. Article (CrossRef Link)

[32] O. C. Richard, A. McMillan-Capehart, S. N. Bhuian, and E. C. Taylor, “Antecedents and consequences of psychological contracts: Does organizational culture really matter?,” J. Bus. Res., vol. 62, no. 8, pp. 818-825, 2009. Article(CrossRef Link)

[33] A. H. Busalim and A. H. C. Razak, "Understanding social commerce: A systematic literature review and directions for further directions for further research,” Int. J. Inf. Manage., vol. 36, no. 6, pp. 1075-1088, 2016. Article(CrossRef Link)

[34] B. O. Han and J. Windsor, "User’s willingness to pay on social network sites,” J. Comput. Inf. Syst., vol. 51, no. 4, pp. 31-40, 2011. Article(CrossRef Link)

[35] J. T. Weng, H. Ting, E. C. de Run, and S. Tan, "Disposition and Repurchase Intention: A Preliminary Study of the How and Why,” Procedia - Soc. Behav. Sci., vol. 224, pp. 332-338, 2016. Article(CrossRef Link)

[36] S. Chu and Y. Kim, "Determinants of consumer engagement in electronic word - of - mouth ( eWOM ) in social networking sites,” Int. J. Advert., vol. 30, no. 1, pp. 47-75, 2011. Article(CrossRef Link)

[37] T.-P. Liang, Y.-T. Ho, Y.-W. Li, and E. Turban, "What Drives Social Commerce: The Role of Social Support and Relationship Quality,” Int. J. Electron. Commer., vol. 16, no. 2, pp. 69-90, 2011. Article(CrossRef Link)

[38] D. Ferrin, M. Bligh, and J. Kohles, "It takes two to tango: an interdependence analysis of the spiraling of perceived trustworthiness and cooperation in interpersonal and intergroup relationships,” Organ. Behav. Hum. Decis. Process., vol. 107, no. 2, pp. 161-178, 2008. Article(CrossRef Link)

[39] N. Hajli, J. Sims, A. H. Zadeh, and M. O. Richard, “A social commerce investigation of the role of trust in a social networking site on purchase intentions,” J. Bus. Res., vol. 71, pp. 133-141, 2017. Article(CrossRef Link)

[40] P. M. Blau, Exchange and power in social life, John Wiley, New York, 1964. Article(CrossRef Link)

[41] J. L. Jones and M. Shandiz, "Service quality expectations: Exploring the importance of SERVQUAL dimensions from different nonprofit constituent groups,” J. Nonprofit Public Sect. Mark., vol. 27, no. 1, pp. 48-69, 2015. Article (CrossRef Link)

[42] O. S. Itani and A. E. Inyang, "The effects of empathy and listening of salespeople on relationship quality in the retail banking industry.," Int. J. Bank Mark., vol. 33, no. 6, pp. 692716, 2015. Article (CrossRef Link)

[43] D. A. McBane, "Empathy and the salesperson: A multidi-mensional perspective," Psychol. Mark., vol. 12, no. 4, pp. 349-370, 1995. Article (CrossRef Link)

[44] S. S. Y. Aw, R. Ilies, and I. E. De Pater, "Dispositional Empathy, Emotional Display Authenticity, and Employee Outcomes,” J. Appl. Psychol., 2019. Article (CrossRef Link)

[45] R. Mayshak, S. J. Sharman, L. Zinkiewicz, and A. Hayley, “The influence of empathy and self-presenta- tion on engagement with social networking website posts," Comput. Human Behav., vol. 71, pp. 362-377, 2017. Article (CrossRef Link) 
[46] W. Bahadur, S. Aziz, and S. Zulfiqar, "Effect of employee empathy on customer satisfaction and loyalty during employee-customer interactions: The mediating role of customer affective commitment and perceived service quality,” Cogent Bus. Manag., vol. 5, no. 1, pp. 1-21, 2018. Article (CrossRef Link)

[47] T. K. Carroll, L. Wang, and D. A. Delaine, "Learning Trip as a Platform for Growth of Empathy," in Proc. of 2018 World Engineering Education Forum - Global Engineering Deans Council (WEEF-GEDC), pp. 1-5, 2018. Article (CrossRef Link)

[48] D. Rousseau and J. Parks, "The contracts of individuals and organizations," Research in organizational behavior, vol. 15. pp. 1-43, 1993. Article(CrossRef Link)

[49] N. Hajli, "The role of social support on relationship quality and social commerce," Technol. Forecast. Soc. Change, vol. 87, pp. 17-27, 2014. Article(CrossRef Link)

[50] G. M. Marakas, R. D. Johnson, and P. F. Clay, "The evolving nature of the computer self-efficacy construct: An empirical investigation of measurement construction, validity, reliability, and stability over time,” J. Assoc. Inf. Syst, vol. 8, pp. 16-46, 2007.

[51] G. D. Garson, Partial Least Squares: Regression \& Structural Equation Models, Statistical Associates Publishers, 2016. Article (CrossRef Link)

[52] J. F. Hair Jr, G. T. M. Hult, C. Ringle, and M. Sarstedt, A Primer on Partial Least Squares Structural Equation Modeling (PLS-SEM), Sage Publications, 2016. Article (CrossRef Link)

[53] C. Höck, C. M. Ringle, and M. Sarstedt, "Management of multi-purpose stadiums: Importance and performance measurement of service interfaces.," Int. J. Serv. Technol. Manag., vol. 14, no. 2/3, pp. 188-207, 2010. Article (CrossRef Link)

[54] C. Fornell and D. F. Larcker, "Evaluating structural equation models with unobservable variables and measurement error.,” J. Mark. Res., vol. 18, no. 1, pp. 39-50, 1981. Article(CrossRef Link)

[55] H. A.M., "Encyclopedia of Quality of Life and Well-Being Research,” Discriminant Validity, M. A.C., Ed. Dordrecht: Springer, pp. 2735-2743, 2014. Article (CrossRef Link)

[56] J. Henseler, C. M. Ringle, and M. Sarstedt, “A New Criterion for Assessing Discriminant Validity in Variance-Based Structural Equation Modeling,” J. Acad. Mark. Sci., vol. 43, no. 1, pp. 115-135, 2015. Article(CrossRef Link)

[57] Petter, S., D. Straub, and A. Rai, "Specifying formative constructs in information systems research,” MIS Q., vol. 31, no. 4, pp. 623-656, 2007. Article(CrossRef Link)

[58] P. M. Podsakoff, S. B. MacKenzie, J. Y. Lee, and N. P. Podsakoff, “Common method biases in behavioral research: a critical review of the literature and recommended remedies,” J. Appl. Psychol., vol. 88, no. 5, p. 879, 2003. Article(CrossRef Link)

[59] W. W. Chin, "Bootstrap Cross-Validation Indices for PLS Path Model Assessment," Handbook of Partial Least Squares, pp. 83-97, 2009. Article (CrossRef Link)

[60] J. Henseler and G. Fassott, "Testing moderating effects in PLS path models: An illustration of available procedures,” Handbook of partial least squares, V. E. Vinzi, W. W. Chin, J. Henseler, and H. Wang, Eds. Heidelberg: Springer, pp. 713-735, 2009. Article(CrossRef Link)

[61] V. E. Vinzi, W. W. Chin, J. Henseler, and H. Wang, "How to write up and report PLS analyses," Handbook of partial least squares: Concepts, methods and application, New York: Springer, pp. 645-689, 2010. Article(CrossRef Link)

[62] S. Helm, A. Eggert, and I. Garnefeld, "Modeling the impact of corporate reputation on customer satisfaction and loyalty using partial least squares," Handbook of partial least squares, V. E. Vinzi, W. W. Chin, J. Henseler, and H. Wang, Eds., pp. 515-534, 2010. Article(CrossRef Link)

[63] J. Cohen, Statistical power analysis for the behavioural sciences, Lawrence Erlbaum Associates Hillsdale, NewJersey, 1988. Article(crossRef Link)

[64] D. P. MacKinnon, C. M. Lockwood, J. M. Hoffman, S. G. West, and V. Sheets, ""A Comparison of Methods to Test Mediation and Other Intervening Variable Effects," Psychol. Methods, vol. 7, no. 1, pp. 83-104, 2002. Article(CrossRef Link)

[65] A. F. Hayes, "Introduction to Mediation, Moderation, and Conditional Process Analysis: A Regression-Based Approach," Guilford Press, 2013. Article(CrossRef Link) 
[66] J. Zhao, J. Wu, X. Feng, H. Xiong, and K. Xu, "Information propagation in online social networks: A tie-strength perspective,” Knowl. Inf. Syst., vol. 32, no. 3, pp. 589-608, 2012. Article(CrossRef Link)

[67] A. Gaskin, J., Godfrey, S., and Vance, "Successful System-use : It' s not just who you are , but what you do,” AIS Trans. HCI, vol. 10, pp. 57-81, 2018. Article(CrossRef Link)

[68] M. Tenenhaus, V. Esposito Vinzi, Y.-M. Chatelin, and C. Lauro, "PLS (Partial Least Squares) path modeling,” Comput. Stat. Data Anal., vol. 48, pp. 159-205, 2005. Article(CrossRef Link)

[69] C. Wetzels, M., Odekerken-Schröder, G., Van Oppen, "Using PLS path modeling for assessing hierarchical construct models: guidelines and empirical illustration.,” MIS Q, vol. 33, pp. 177195, 2009. Article(CrossRef Link)

[70] D. Aaker, "Building a brand: The Saturn story,” Calif. Manage. Rev., vol. 36, pp. 114-133, 2004. Article (CrossRef Link)

[71] J. Mcalexander, J. Schouten, and H. Koenig, "Building a brand community,” J. Mark., vol. 66, pp. 38-54, 2002. Article (CrossRef Link)

[72] P. Verhoef, "Understanding the effect of relationship management efforts on customer retention and customer share development,” J. Mark., vol. 67, pp. 30-45, 2003. Article (CrossRef Link)

[73] G. E. Dabos and D. M. Rousseau, "Mutuality and Reciprocity in the Psychological Contracts of Employees and Employers,” J. Appl. Psychol., vol. 89, no. 1, pp. 52-72, 2004.

Article(CrossRef Link)

[74] C. M. Chiu, C. C. Chang, H. L. Cheng, and Y. H. Fang, "Determinants of customer repurchase intention in online shopping," Online Inf. Rev., vol. 33, no. 4, pp. 761-784, 2009. Article(CrossRef Link)

[75] S. Roma, "The Ethics of Online Retailing: A Scale Development and Validation from the Consumers’ Perspective,” J. Bus. Ethics, vol. 72, pp. 131-148, 2007. Article(CrossRef Link)

[76] B. CP, F. DJ, M. MB, and S. SF, "Proactive customer orientation and its role for creating customer value in global markets,” J. ofthe Acad. ofMarketing Sci., vol. 39, no. 2, pp. 216-233, 2011. Article(CrossRef Link)

[77] M. N. Hajli, “Social commerce for innovation,” Int. J. Innov. Manag., vol. 18, no. 04, pp. 1-24, Aug. 2014. Article(CrossRef Link)

[78] A. Parasuraman, V. A. Zeithaml, and L. L. Berry, "Alternative scales for measuring service quality: A comparative assessment based on psychometric and diagnostic criteria.,” J. Retail., vol. 70, no. 3, pp. 201-230, 1994. Article(CrossRef Link)

\section{Appendix: Measurement Instrument}

\begin{tabular}{|l|l|c|}
\hline Items & $\begin{array}{l}\text { Factor } \\
\text { Loading }\end{array}$ \\
\hline Consumers' trust in Platform [73] & $\mathbf{0 . 7 7 3}$ \\
\hline CT1 & I am sure I fully trust my platform. & $\mathbf{0 . 9 7 1}$ \\
\hline CT2 & The platform is secured and upfront with me. & $\mathbf{0 . 8 1 2}$ \\
\hline CT3 & I believe my platform has high integrity. & $\mathbf{0 . 9 1 8}$ \\
\hline CT4 & In general, I believe my platform's motives and intentions are good. & $\mathbf{0 . 8 2 4}$ \\
\hline CT5 & My platform is always honest and truthful. & $\mathbf{0 . 8 0 1}$ \\
\hline CT6 & I think my platform treats me fairly. & $\mathbf{0 . 7 9 4}$ \\
\hline CT7 & I can expect my platform to treat me consistently and predictably. & \\
\hline Psychological contract Fulfilment [73][11] & $\mathbf{0 . 8 6 2}$ \\
\hline PCF1 & $\begin{array}{l}\text { The platform does not exaggerate the benefits and characteristics of } \\
\text { its offerings. }\end{array}$ & $\mathbf{0 . 8 4 6}$ \\
\hline PCF2 & The platform is entirely truthful about its offerings. & $\mathbf{0 . 8 5 3}$ \\
\hline PCF3 & The platform never uses misleading tactics to convince consumers & \\
\hline
\end{tabular}




\begin{tabular}{|c|c|c|}
\hline & to rebuy their products. & \\
\hline PCF4 & $\begin{array}{l}\text { This platform never takes advantage of less experienced consumers } \\
\text { to ask the repurchase. }\end{array}$ & $\mathbf{0 . 7 8 4}$ \\
\hline PCF5 & $\begin{array}{l}\text { This platform never attempts to persuade you to rebuy things that } \\
\text { you do not need. }\end{array}$ & 0.804 \\
\hline PCF6 & $\begin{array}{l}\text { This platform always tries to make a good relationship with its } \\
\text { consumers by providing informational and emotional support. }\end{array}$ & 0.825 \\
\hline PCF7 & This platform is always ready to help. & 0.875 \\
\hline PCF8 & $\begin{array}{l}\text { This platform always tries to build a win-win situation for } \\
\text { consumers. }\end{array}$ & 0.785 \\
\hline \multicolumn{3}{|c|}{ Repurchase Intention [74][75] } \\
\hline RI1 & $\begin{array}{l}\text { If I could, I would like to continue using this platform to purchase } \\
\text { products }\end{array}$ & 0.853 \\
\hline RI2 & $\begin{array}{l}\text { I will likely continue purchasing products from this platform in the } \\
\text { future }\end{array}$ & 0.884 \\
\hline RI3 & $\begin{array}{l}\text { I intend to continue purchasing products from this platform in the } \\
\text { future }\end{array}$ & 0.915 \\
\hline \multicolumn{3}{|c|}{ Consumer Loyalty [76] } \\
\hline CL1 & $\begin{array}{l}\text { Given that there is a need, we intend to continue doing business } \\
\text { with this provider for the foreseeable future }\end{array}$ & 0.923 \\
\hline CL2 & $\begin{array}{l}\text { Given that there is a need, how likely is it that your firm will } \\
\text { continue doing business with this provider during the next year? }\end{array}$ & 0.852 \\
\hline CL3 & $\begin{array}{l}\text { Given that there is a need, how likely is it that your firm will } \\
\text { continue doing business with this provider during the next } 3 \text { to } \\
5 \text { years? }\end{array}$ & 0.888 \\
\hline \multicolumn{3}{|c|}{ Affective commitment [77][37] } \\
\hline AC1 & The platform provides me with the opportunity to learn. & $\mathbf{0 . 8 8 6}$ \\
\hline AC2 & $\begin{array}{l}\text { The platform helps both me and others to communicate openly in } \\
\text { the form of feedback and reviews. }\end{array}$ & 0.907 \\
\hline AC3 & On-site, some people would offer suggestions when I need help. & $\mathbf{0 . 8 6 0}$ \\
\hline \multicolumn{3}{|c|}{ Platform empathy [78] } \\
\hline PE1 & The platform gives consumers individual attention. & $\mathbf{0 . 8 8 6}$ \\
\hline PE2 & The platform deals with consumers in a caring fashion. & 0.894 \\
\hline PE3 & The platform has the consumers best interest at heart. & 0.772 \\
\hline PE4 & The platform understands the needs of its consumers. & 0.859 \\
\hline
\end{tabular}




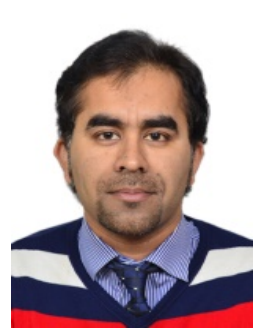

Shahbaz Hussain is currently working as a Lecturer in Business Administration at University of Okara. He received his M. Phil degree in Management Sciences from National University of Modern Languages Islamabad, Multan campus in 2014. Mr. Hussain is pursuing his Ph.D. in Management Sciences and Engineering at Dalian University of Technology, Dalian, China. He has published several research articles in International, peer-reviewed and SCI journals. His research interests include consumer behavior, consumer psychology, and CRM.

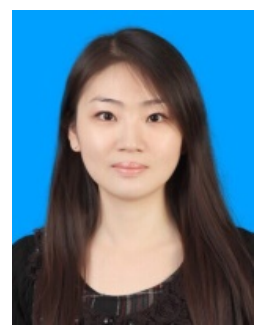

Dr. Li Ying is currently working as associate professor in School of Economics and Management, Dalian University of Technology. She obtained her doctor degree in information processing from Oulu University, Finland in 2015. She is a member of Association for Information Systems (AIS). Her academic achievements have been published in the several international, SCI journals. Her research interests include information security behaviors, management information systems, and social commerce.

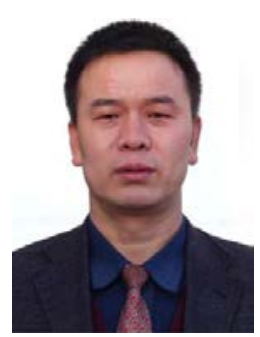

Mr. Li Wenli is currently working as Professor in School of Economics and Management, Dalian University of Technology. His research interests include mainly, e-commerce, information management, and trust in social commerce. He is acting Chairman of Liaoning Province E-commerce Education Steering Committee. He has chaired 6 National Natural Science Foundation projects, 6 provincial and ministerial projects, and published more than 100 papers in well reputed academic conferences and journals. 